Structural conversi on frombow - to bal I-type pol yoxovanadates: Synt hesi s of a spherical tet $r$ adecavanadate through a chl or i de- i ncor por at ed bow - type dodecavanadate

\begin{tabular}{|l|l|}
\hline 著者 & $\begin{array}{l}\text { Kobayashi Tet suhi ro, Kuwaj i ma Sho, Kur at a } \\
\text { Tai sei, Hayashi Yoshi hi t o }\end{array}$ \\
\hline $\begin{array}{l}\text { j our nal or } \\
\text { publ i cat i on ti t l e }\end{array}$ & I norgani ca Chi mi ca Act a \\
\hline vol une & 420 \\
\hline page r ange & $69-74$ \\
\hline year & 2014 08 24 \\
\hline URL & ht t p: //hdl . handl e. net /2297/39097 \\
\hline
\end{tabular}




\section{Structural conversion from bowl- to ball-type polyoxovanadates: Synthesis of a spherical tetradecavanadate through a chloride-incorporated bowl-type dodecavanadate}

Tetsuhiro Kobayashi, Sho Kuwajima, Taisei Kurata and Yoshihito Hayashi*

Department of Chemistry, Kanazawa University, Kakuma, Kanazawa, 920-1192, Japan

\section{Synopsis}

A bowl-shaped polyoxovanadate, $\left[\mathrm{V}_{12} \mathrm{O}_{32}(\mathrm{Cl})\right]^{5-}$, was transformed to a spherical polyoxovanadate, $\left[\mathrm{V}_{14} \mathrm{O}_{38}(\mathrm{Cl})\right]^{7-}$ with all of the vanadium atoms in the $\mathrm{V}(\mathrm{V})$ oxidation state. The chloride guest was completely enclosed within the spherical cage by a bowl- to ball-type structural conversion.

\section{Disk, Bowl to Ball}

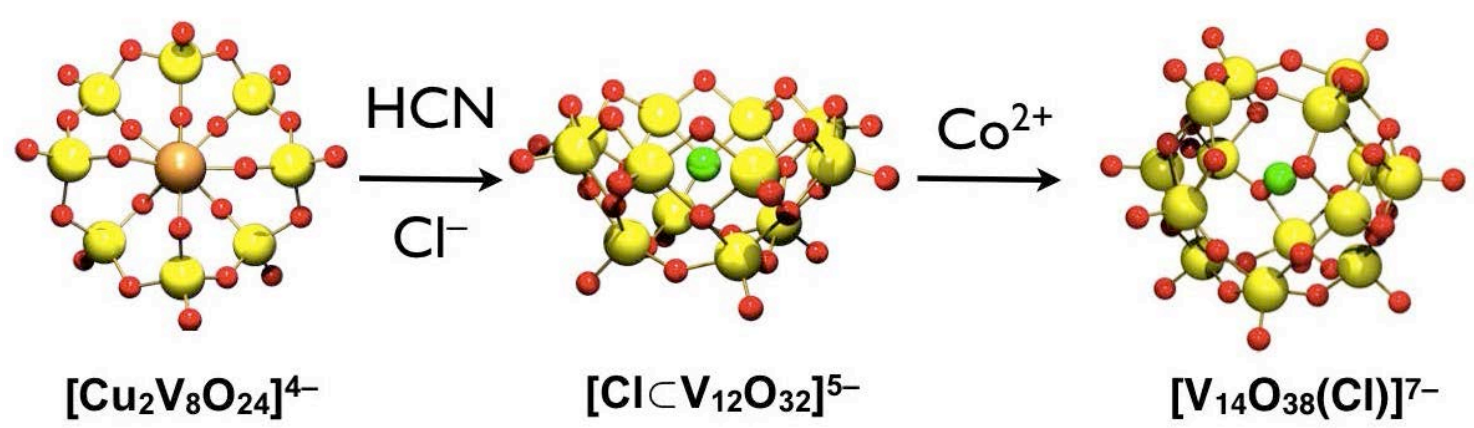




\section{ABSTRACT}

A spherical tetradecavanadate, $\left[\mathrm{V}_{14} \mathrm{O}_{38}(\mathrm{Cl})\right]^{7-}$, was synthesized from a chloride-incorporated bowl-type dodecavanadate, $\left[\mathrm{ClC} \mathrm{V}_{12} \mathrm{O}_{32}\right]^{5-}$, which was prepared through a template switching reaction from $\left[\mathrm{Cu}_{2} \mathrm{~V}_{8} \mathrm{O}_{24}\right]^{4-}$ using the cation template removal reagent, hydrogen cyanide. X-ray structure analysis revealed a spherical V(V) polyoxovanadate framework, without $\mathrm{V}(\mathrm{IV})$ valence state. The two-step process, involving transformation of a disk to a bowl, then transformation from the bowl to a ball, enables the incorporation of a guest anion inside the ball. An alternative route from a hexadecavanadate, which avoids the use of hydrogen cyanide, is also described.

\section{Keywords:}

Polyoxometalates, Polyoxovanadates, Host-guest chemistry, Vanadium

* Corresponding author. Tel.: +81-76-264-5695; fax: +81-76-264-5742.

E-mail address: hayashi@se.kanazawa-u.ac.jp.

\section{Introduction}

The design and synthesis of a host oxide-molecule is a current challenge in inorganic chemistry [1-4]. Super-molecular oxide molecules offer many potential applications, such as molecular recognition, transformation, and translocation. Some giant spherical polyoxomolybdates have been described, including spheres composed of hundreds of metal atoms that exhibited biological cell-like functions that restrict the ability of a guest molecule to move in and out of the cage [5-8]. For translocation, the development of a synthetic route to enable access to the cavity is necessary. The method reported here uses polyoxovanadate, $\left[\mathrm{Cl} \subset \mathrm{V}_{12} \mathrm{O}_{32}\right]^{5-}[9]$. The approach demonstrates a synthetic pathway to spherical polyoxovanadates using a capping reaction on the half-spherical bowl-type molecule, which can complete the sphere after incorporation of a guest anion inside the bowl-type host molecule.

The dodecavanadate $\left[\mathrm{CH}_{3} \mathrm{CN} \subset\left(\mathrm{V}_{12} \mathrm{O}_{32}\right)\right]^{4-}$ is a basket-shaped host molecule that incorporates an acetonitrile guest at the center of the cavity with the nitrile group and not 
the methyl group, which was oriented inward toward the anionic basket [10]. The benzonitrile guest complex $\left[\mathrm{C}_{6} \mathrm{H}_{5} \mathrm{CNC}\left(\mathrm{V}_{12} \mathrm{O}_{32}\right)\right]^{4-}$ also has been prepared, with a binding preference of acetonitrile over benzonitrile [11]. Incorporation of guest $\mathrm{NO}^{-}$ anions has also been reported [12]. In the "electronically inverse" host-guest system, which appears to be a seemingly contradictory phenomenon, an anionic guest is placed inside the anionic cage. The electrostatic balances of these clusters with the high-valent vanadium cation are studied by $a b$ initio modeling $[13,14]$. The guest inside the bowl-shaped dodecavanadates are relatively free to dissociate due to their open frameworks.

Host polyoxovanadates with a ball-shaped structure were reported in a mixed valence state of $\mathrm{V}(\mathrm{V}) / \mathrm{V}(\mathrm{IV})$. The encapsulation of small anions, such as $\mathrm{X}^{-}\left(\mathrm{Cl}^{-}, \mathrm{Br}^{-}, \mathrm{I}^{-}\right), \mathrm{NO}_{3}{ }^{-}$, $\mathrm{CO}_{3}{ }^{2-}, \mathrm{N}_{3}{ }^{-}, \mathrm{ClO}_{4}{ }^{-}$, or $\mathrm{CN}^{-}$, in an anionic spherical cage were studied utilizing a template effect [15-19]. The electrostatic balance between an anionic template and a polyoxovanadate framework influenced the resulting structure of the sphere; i.e., the combination of weak repulsion with the polyoxovanadate oxygen atoms and the attraction of the vanadium cationic center (the highest valence state of $\mathrm{V}(\mathrm{V})$ ) controlled the architecture of the anion-templated polyoxovanadate cage. The reduced spherical polyoxovanadates produced a deep blue color due to intervalence transition bands. Instead of the reduced framework, the all-V(V) spherical polyoxovanadates exhibit decreased negative-negative repulsion between the guest anion and host cage, and it is our aim to develop an anion inside anion molecule by taking advantage of the favorable electrostatic balance. The spherical polyoxovanadates in an all-V(V) oxidation state was reported as a lacunary form, $\left[\mathrm{HV}_{12} \mathrm{O}_{32}(\mathrm{Cl})\right]^{4-}[20]$.

Hybrid materials between organo-arsonate or phosphonate ligands with polyoxovanadates also have been reported through formation of a unique host system that can bind guest anions inside the hybrid cages. In those hybrid complexes, a square arrangement of vanadium atoms in a $\left[\mathrm{V}_{4} \mathrm{O}_{8}\right]^{4+}$ unit was used as a capping group in the host system; the square unit plays a fundamental role in anion binding [21-25].

New coordination chemistry involving inorganic ligands of cyclic polyoxovanadates has been developed [26]. Inorganic complexes between a crown-type polyoxovanadate, $\left(\mathrm{VO}_{3}\right)_{n}{ }^{n-}$, and a transition metal cation produced a type of inorganic coordination complexes with a vanadium ring size of $4<n<10$, depending on the type of metal cation used as a template [27-30]. To elucidate the reactivity of all-inorganic coordination 
complexes, a template-removal reaction was developed using the copper complex, $\left[\mathrm{Cu}_{2} \mathrm{~V}_{8} \mathrm{O}_{24}\right]^{4-}[31]$. Here, the synthesis and structural studies of ball-shaped polyoxovanadate $(\mathrm{V})$ are reported. The course of the synthesis is described in a stepwise manner: copper template removal from the disk-shaped macrocyclic copper complex $\left[\mathrm{Cu}_{2} \mathrm{~V}_{8} \mathrm{O}_{24}\right]^{4-}$ was performed to give bowl-shaped dodecavanadates with a chloride template, $\left[\mathrm{Cl} \subset \mathrm{V}_{12} \mathrm{O}_{32}\right]^{5-}$; then the bowl was capped to complete the ball using a Lewis acid to afford $\left[\mathrm{V}_{14} \mathrm{O}_{38}(\mathrm{Cl})\right]^{7-}$ with a structural rearrangement. The ${ }^{51} \mathrm{~V}$ NMR spectra were then used to analyze the reaction and elucidate the structure of the complexes. An alternative route to synthesize $\left[\mathrm{Cl} \subset \mathrm{V}_{12} \mathrm{O}_{32}\right]^{5-}$ without using hydrogen cyanide also was explored.

\section{Experimental}

\subsection{Materials and methods}

All reactions and manipulations were conducted under a nitrogen atmosphere using Schlenck techniques. All reagent-grade chemicals were purchased and used without further purification. The starting complexes, $\left(n-\mathrm{Bu}_{4} \mathrm{~N}\right)_{4}\left[\mathrm{Cu}_{2} \mathrm{~V}_{8} \mathrm{O}_{24}\right]$, $\left(n-\mathrm{Et}_{4} \mathrm{~N}\right)_{4}\left[\mathrm{Cu}_{2} \mathrm{~V}_{8} \mathrm{O}_{24}\right]$ and $\left(\mathrm{PPh}_{4}\right)_{2}\left[\mathrm{~V}_{6} \mathrm{O}_{13}\left(\mathrm{OCH}_{3}\right)_{6}\right]$ were synthesized according to published procedures $[31,32]$. The purity of the crystals obtained was confirmed by FT-IR spectroscopy. Acetonitrile was distilled over $\mathrm{P}_{2} \mathrm{O}_{5}$ under a nitrogen atmosphere and stored in a sealed glass vessel. The UV-visible spectra were recorded using a Hitachi U-3500 spectrophotometer. The C, H and $\mathrm{N}$ elemental analyses were performed at the Research Institute for Instrumental Analysis at Kanazawa University. Elemental analyses of $\mathrm{Cl}$ were performed by the Center for Organic Elemental Microanalysis Laboratory at Kyoto University. IR spectra were obtained on samples prepared as Nujor mulls between KBr plates on a Horiba FT-720 spectrophotometer. The ${ }^{51} \mathrm{~V}$ NMR spectra were recorded on a JEOL JNM-LA400 spectrometer at $105.04 \mathrm{MHz}$ in $\mathrm{CH}_{3} \mathrm{CN}$. Chemical shifts were externally referenced to neat $\operatorname{VOCl}_{3}(\delta=0 \mathrm{ppm})$. An ALS/CH Instruments electrochemical analyzer (Model 600A) was used for voltammetric experiments. The working electrode was glassy carbon, the counter electrode was Pt wire, and the reference 
electrode was $\mathrm{Ag} / \mathrm{Ag}^{+}$. The redox potential $\left(\mathrm{E}_{1 / 2}\right.$ value $)$ of ferrocene $\left(\mathrm{Fc} / \mathrm{Fc}^{+}\right)$versus the $\mathrm{Ag} / \mathrm{Ag}^{+}$reference electrode was $28 \mathrm{mV}$ with a $58 \mathrm{mV}$ peak separation in our experiments. Electrospray mass spectra were recorded on a micromass LCT mass spectrometer. A 1.0 $\mathrm{cm}^{3}$ aliquot of an acetonitrile solution was injected directly for ESI MS analysis. The tip of the capillary and the sampling cone were maintained at potentials of $-1400 \mathrm{~V}$ and $-2 \mathrm{~V}$, respectively. The source temperature was $25^{\circ} \mathrm{C}$. The $\mathrm{m} / \mathrm{z}$ values refer to the highest peak of the ion clusters.

\subsection{Synthesis of $\left(n-E t_{4} N\right)_{5}\left[C l \subset V_{12} O_{32}\right]$ (1)}

Method (a). The template removal reaction was performed by bubbling HCN gas into $2 \mathrm{~mL}$ of an acetonitrile solution of the mixture of $\left(n-\mathrm{Bu}_{4} \mathrm{~N}\right)_{4}\left[\mathrm{Cu}_{2} \mathrm{~V}_{8} \mathrm{O}_{24}\right](100 \mathrm{mg}, 0.05$ mmol) and $\mathrm{Et}_{4} \mathrm{NCl}(350 \mathrm{mg}, 2.1 \mathrm{mmol})$. A small excess amount of $\mathrm{HCN}$ gas was produced from the reaction of sulfuric acid and solid $\mathrm{NaCN}$ and bubbled through the mixture solution using a Teflon tube. The color of the solution changed from green to red-brown, and the mixture was stirred at $25^{\circ} \mathrm{C}$. After $1 \mathrm{~h}$, a brown precipitate was produced and collected as a crude product. From the filtrate, colorless crystals of $\left\{\left(\mathrm{C}_{2} \mathrm{H}_{5}\right)_{4} \mathrm{~N}\right\}\left[\mathrm{Cu}_{2}(\mathrm{CN})_{3}\right]$ were obtained after further crystallization of $\mathbf{1}$, and the complex was crystallographically identified [9,33]. The precipitate was redissolved in acetonitrile and recrystallized to give the product as brown crystals (30 $\mathrm{mg}, 33 \%$ based on V). Anal. Calc. for $\mathrm{C}_{42} \mathrm{H}_{103} \mathrm{~N}_{6} \mathrm{ClO}_{32} \mathrm{~V}_{12}$ : C, 27.25; H, 5.61; N, 4.54; Cl, 1.92. Found: $\mathrm{C}$, 27.18; H, 5.73; N, 4.50; Cl, 2.07\%. IR (Nujol, 1000-500 cm $\mathrm{cm}^{-1}$ ): 997(s), 979(s), 968(s), 848(m), 750(m), 721(m), 624(sh), 590(sh). ${ }^{51} \mathrm{~V}$ NMR $\left(\mathrm{CH}_{3} \mathrm{CN}\right): \delta=-579(4 \mathrm{~V}),-587$ $(4 \mathrm{~V}),-597(4 \mathrm{~V})$.

Method (b). To avoid the use of poisonous $\mathrm{HCN}$ gas, a coupling reaction of hexamethoxo-hexavanadate was performed. A $\left(\left(\mathrm{C}_{6} \mathrm{H}_{5}\right)_{4} \mathrm{P}\right)_{2}\left[\mathrm{~V}_{6} \mathrm{O}_{13}(\mathrm{OMe})_{6}\right](500 \mathrm{mg}$, $0.363 \mathrm{mmol})$ solution in dichloromethane $(12.0 \mathrm{~mL})$ was added to a stock solution of i-propanol $(4.0 \mathrm{~mL})$ with six equivalents of water and the solution was stirred for several minutes until an orange homogeneous solution was obtained. Complete evaporation of the solvents under reduced pressure gave orange solids. The dried powder was dissolved in dichloromethane $(5 \mathrm{~mL})$ followed by addition of $\left(\mathrm{C}_{2} \mathrm{H}_{5}\right)_{4} \mathrm{NCl}(300 \mathrm{mg}, 1.81 \mathrm{mmol})$. 
The mixture was stirred for ten minutes followed by addition of diethyl ether, which caused a brown powder to precipitate. The brown powder was collected and washed with dichloromethane, then diethyl ether, and was dissolved in nitromethane $(8.0 \mathrm{~mL})$. The addition of diethyl ether was carefully controlled to avoid immediate formation of precipitates and left to allow recrystallization. After one day, $92.9 \mathrm{mg}$ of brown crystals were obtained in a $28 \%$ yield based on V. The IR and ${ }^{51} \mathrm{~V}$ NMR spectra were identical to the complex synthesized in method $(a)$.

\subsection{Synthesis of $\left(n-E t_{4} N\right)_{2}\left(\left(C_{6} H_{5}\right)_{4} P\right)_{3}\left[H_{2} V_{14} O_{38}(C l)\right](2)$}

A mixture of $\left(\left(\mathrm{C}_{2} \mathrm{H}_{5}\right)_{4} \mathrm{~N}\right)_{5}\left[\mathrm{Cl} \subset \mathrm{V}_{12} \mathrm{O}_{32}\right](80 \mathrm{mg}, 0.05 \mathrm{mmol}),\left(n-\mathrm{C}_{4} \mathrm{H}_{9}\right)_{4} \mathrm{NCl}(400 \mathrm{mg}$, $1.4 \mathrm{mmol})$, and $\mathrm{Co}\left(\mathrm{NO}_{3}\right)_{2} \cdot 6 \mathrm{H}_{2} \mathrm{O}(15 \mathrm{mg}, 0.05 \mathrm{mmol})$ in $2 \mathrm{~mL}$ acetonitrile was allowed to stand for 2 days at $25^{\circ} \mathrm{C}$. The addition of $\left(\mathrm{C}_{2} \mathrm{H}_{5}\right)_{4} \mathrm{NCl}(350 \mathrm{mg}, 2.1 \mathrm{mmol})$ to the mixture produced a brown precipitate after $1 \mathrm{~h}$. The crude product was collected and washed with acetonitrile three times. After suspending the precipitate in acetonitrile, $\left(\mathrm{C}_{6} \mathrm{H}_{5}\right)_{4} \mathrm{PBr}(210$ $\mathrm{mg}, 0.5 \mathrm{mmol}$ ) was added and stirred to give a red-brown solution. After filtering any undissolved material, brown crystals of $\left(\left(\mathrm{C}_{2} \mathrm{H}_{5}\right)_{4} \mathrm{~N}\right)_{2}\left(\left(\mathrm{C}_{6} \mathrm{H}_{5}\right)_{4} \mathrm{P}\right)_{3}\left[\mathrm{H}_{2} \mathrm{~V}_{14} \mathrm{O}_{38} \mathrm{Cl}\right]$ were obtained (10 mg, 9\% based on V). Anal. Calc. for $\mathrm{C}_{88} \mathrm{H}_{102} \mathrm{~N}_{2} \mathrm{ClO}_{38} \mathrm{P}_{3} \mathrm{~V}_{14}: \mathrm{C}, 40.08 ; \mathrm{H}$, $3.90 ; \mathrm{N}, 1.06 ; \mathrm{Cl}, 1.34$. Found: C, 39.76; H, 3.93; N, 1.10; Cl, 1.28\%. IR (Nujol, 1000$\left.500 \mathrm{~cm}^{-1}\right)$ : 978(s), 914(w), 842(s), 787(w), 750(m), 721(s), 688(w), 647(m), 522(w). ${ }^{51} \mathrm{~V}$ $\mathrm{NMR}\left(\mathrm{CH}_{3} \mathrm{CN}\right): \delta=-547(2 \mathrm{~V}),-567(2 \mathrm{~V}),-579(6 \mathrm{~V}),-592(4 \mathrm{~V})$.

\subsection{Synthesis of $\left(n-E t_{4} N\right)_{5}\left[H_{2} V_{14} O_{38}(C l)\right]$ (2a)}

The addition of $\mathrm{ZrOCl}_{2} \cdot 8 \mathrm{H}_{2} \mathrm{O}(58 \mathrm{mg}, 0.181 \mathrm{mmol})$ in $1.0 \mathrm{~mL}$ methanol to a $10 \mathrm{~mL}$ dichloromethane solution of $\left(\left(\mathrm{C}_{6} \mathrm{H}_{5}\right)_{4} \mathrm{P}\right)_{2}\left[\mathrm{~V}_{6} \mathrm{O}_{13}(\mathrm{OMe})_{6}\right](500 \mathrm{mg}, 0.363 \mathrm{mmol})$ gave a homogeneous solution that was stirred overnight. After filtering pale-yellow material, yellow crystals were obtained by adding $40 \mathrm{~mL}$ of diethyl ether with diffusion of ethyl acetate into the solution. Yields: $72.5 \mathrm{mg}, 23 \%$ based on $\mathrm{V}$.

Anal. Calc. for $\mathrm{C}_{40} \mathrm{H}_{102} \mathrm{~N}_{5} \mathrm{ClO}_{38} \mathrm{P}_{3} \mathrm{~V}_{14}$ : C, 23.90; H, 5.12; N, 3.48; Cl, 1.34. Found: $\mathrm{C}$, 23.89; H, 5.02; N, 3.48; Cl, 1.28\%. IR ( $\left.\mathrm{KBr}, 1000-500 \mathrm{~cm}^{-1}\right)$ : 984(s), 849(s), 789(w), 
760(m), 660(m), 592(w). ${ }^{51} \mathrm{~V}$ NMR $\left(\mathrm{CH}_{3} \mathrm{CN}\right): \delta=-545(2 \mathrm{~V}),-566(2 \mathrm{~V}),-579(6 \mathrm{~V}),-$ $589(4 \mathrm{~V})$.

\subsection{X-ray crystal structure determinations}

Well-shaped crystals from the mother liquor were mounted in Hamilton cryoloops into the diffractometer and frozen immediately. Intensity data were collected at $-150{ }^{\circ} \mathrm{C}$ using a Rigaku/MSC mercury diffractometer with graphite monochromic Mo-K $\alpha$ radiation ( $\lambda$ $=0.71073 \AA$ ), by $0.5^{\circ} \omega$-scans at $0^{\circ}$ and $90^{\circ}$ in $\phi$. Information on data collection and structure refinement, including the final cell constants, are listed in Table 1. Based on statistical analysis of intensity distribution and on successful solution and refinement of the structure, the space group was determined to be I222. Data were collected and processed using the CrystalClear program (Rigaku). Absorption corrections were applied based on the face-indexing method. Direct methods were used to solve the structure and to locate the heavy atoms. The light atoms were found through successive refinements by the full-matrix least square methods using the SHELXL-97 program [34]. The program PLATON was used to evaluate the accuracy of the refinements, space group choice, and the lack of higher symmetry [35]. 


\section{Table 1}

Crystal structure data and refinement details for $\mathbf{2}$.

Formula

$M\left(\mathrm{~g} \mathrm{~mol}^{-1}\right)$

$T\left({ }^{\circ} \mathrm{C}\right)$

Crystal system

Space group

Unit cell dimensions

$a(\AA)$

$b(\AA)$

$c(\AA)$

$V\left(\AA^{3}\right)$

Z

$\rho\left(\mathrm{g} \mathrm{cm}^{-3}\right)$

$\mu\left(\mathrm{mm}^{-1}\right)$

Size

$F(000)$

$\theta \max \left({ }^{\circ}\right)$

Reflection collected

$T_{\max , \min }$

Unique reflections $\left(R_{\text {int }}\right)$

Flack parameter

$R_{1}{ }^{\mathrm{a}}[I>2 \sigma(I)]$

$w R_{2}{ }^{\mathrm{b}}$ (all data)
$\mathrm{C}_{40} \mathrm{H}_{100} \mathrm{ClN}_{5} \mathrm{O}_{38} \mathrm{~V}_{14}$

2007.9

$-150$

Orthorhombic

I222

$12.863(2)$

14.243(3)

20.852(4)

$3820.3(12)$

2

1.756

1.745

$0.2 \times 0.2 \times 0.2$

2036

29.57

22118

$0.9174,0.7969$

$3790(0.0266)$

$0.06(7)$

0.0857

0.237

Goodness-of-fit (GOF) on $F^{2} 1.093$

\footnotetext{
${ }^{\mathrm{a}} R_{1}=\Sigma|| F_{\mathrm{o}}|-| F_{\mathrm{c}}|| / \Sigma\left|F_{\mathrm{o}}\right|$

${ }^{\mathrm{b}} w R_{2}=\left\{\Sigma w\left(F_{\mathrm{o}}{ }^{2}-F_{\mathrm{c}}{ }^{2}\right) / \Sigma w\left(F_{\mathrm{o}}{ }^{2}\right)^{2}\right\}^{1 / 2}$
} 


\section{Results and Discussion}

\subsection{Syntheses}

The bowl-shaped dodecavanadate anion, $\left[\mathrm{V}_{12} \mathrm{O}_{32}\right]^{4-}$ can be considered as an assembly of two separate groups; the rim of the bowl, a cyclic $\left[\mathrm{V}_{8} \mathrm{O}_{24}\right]^{8-}$ group, and the bottom of the bowl, a rectangular $\left[\mathrm{V}_{4} \mathrm{O}_{8}\right]^{4+}$ unit. The all-inorganic complex $\left[\mathrm{Cu}_{2} \mathrm{~V}_{8} \mathrm{O}_{24}\right]^{4-}$ contains a cyclic octameric vanadium ring, $\left[\mathrm{V}_{8} \mathrm{O}_{24}\right]^{8-}$, as a macrocyclic ligand that coincides with the formula of the rim unit of the bowl. If the two $\mathrm{Cu}$ atoms can be removed, a synthetic path is created that may allow the cyclic structure to be used as the rim of the $\left[\mathrm{V}_{12} \mathrm{O}_{32}\right]^{4-}$ bowl (Scheme 1). To determine the feasibility of this, the similarities between these new inorganic macrocyclic complexes and organic-macrocyclic chemistry were exploited. Template synthesis is often employed for tetraaza-macrocycle chemistry, and the demetallation reaction may form free ligands that can be used in synthetic methods. To remove the cationic metal template, cyanide and ammonia have been used to liberate macrocycles [36]. Removal by strong acid or applicatioin of a redox reaction was not appropriate for our purpose due to the instability of polyoxovanadates under the conditions needed. Therefore, removal of $\mathrm{Cu}^{2+}$ using either ethylenediamine or hydrogen cyanide as template removal reagents was explored. The first approach involved the use of amine ligands. Ethylenediamine was chosen because of its ability to effectively chelate $\mathrm{Cu}^{2+}$ cations. Addition of ethylenediamine to an acetonitrile solution of $\left[\mathrm{Cu}_{2} \mathrm{~V}_{8} \mathrm{O}_{24}\right]^{4-}$ caused the light green solution to turn a copper blue color, which clearly indicated that template removal was successful. However, the polyoxovanadate unit decomposed into the $\left[\mathrm{V}_{4} \mathrm{O}_{12}\right]^{4-}$ form, revealed by the chemical shift of ${ }^{51} \mathrm{~V}$ NMR at -569 ppm and peaks based on $\left[\mathrm{V}_{3} \mathrm{O}_{9}\right]^{3-}$ and $\left[\mathrm{V}_{4} \mathrm{O}_{12}\right]^{4-}$ in the ESI mass spectra of the solution. The second approach that was attempted involved hydrogen cyanide, which was shown to be the best method for removal of copper atoms. Since the macrocyclic polyoxovanadate appears to be in an equilibrium involving different species in an uncomplexed state, isolation of $\left[\mathrm{V}_{8} \mathrm{O}_{24}\right]^{8-}$ species was not attempted. However, ESI mass spectra of the reaction mixture contained peaks related to the liberated $\left[\mathrm{V}_{8} \mathrm{O}_{24}\right]^{8-}$ (peak no. 7 in Fig. S1) with $\left[\mathrm{CuV}_{8} \mathrm{O}_{24}\right]^{2-}$ and $\left[\mathrm{Cu}_{2} \mathrm{~V}_{8} \mathrm{O}_{24}\right]^{4-}$ species along with the $\left[\left(\mathrm{CH}_{3} \mathrm{CN}\right) \subset \mathrm{V}_{12} \mathrm{O}_{32}\right]^{4-}$ species (Fig. S1 and Table S1). A slight excess of hydrogen cyanide (12 equivalents) was 
bubbled through the acetonitrile solution of $\left[\mathrm{Cu}_{2} \mathrm{~V}_{8} \mathrm{O}_{24}\right]^{4-}$ with the chloride anion template, to obtain bowl-type $\mathbf{1}$ with an incorporated chloride anion. In this reaction, the template polarity was changed from cationic $\mathrm{Cu}^{2+}$ to anionic $\mathrm{Cl}^{-}$. The copper cation was coordinated by an oxido-group in the $\mathrm{VO}_{4}$ unit in $\left[\mathrm{Cu}_{2} \mathrm{~V}_{8} \mathrm{O}_{24}\right]^{4-}$, while the chloride template was kept inside the bowl cavity through weak interactions at the basal plane of pyramidal $\mathrm{VO}_{5}$ units in the bowl-type $\left[\mathrm{V}_{12} \mathrm{O}_{32}\right]^{4-}$ cage. The overall stoichiometry of the reactions is summarized in Eq. (1).

$3\left[\mathrm{Cu}_{2} \mathrm{~V}_{8} \mathrm{O}_{24}\right]^{4-}+15 \mathrm{HCN}+\mathrm{HCl}+\mathrm{Cl}^{-} \rightarrow 2\left[\mathrm{ClCV}{ }_{12} \mathrm{O}_{32}\right]^{5-}+3\left[\mathrm{Cu}_{2}(\mathrm{CN})_{3}\right]^{-}+3(\mathrm{CN})_{2}+$ $8 \mathrm{H}_{2} \mathrm{O}$

In this reaction, a chloride-incorporated dodecavanadate was obtained in $20 \%$ yield. Without the presence of excess amount of chloride, acetonitrile-incorporated $\left[\left(\mathrm{CH}_{3} \mathrm{CN}\right)\right.$ $\left.\mathrm{CV}_{12} \mathrm{O}_{32}\right]^{4-}$ was also formed. Analysis of the ${ }^{51} \mathrm{~V}$ NMR spectra revealed that 40 equivalents of chloride anion were necessary to selectively produce complex $\mathbf{1}$, otherwise a mixture of $\mathbf{1}$ and $\left[\left(\mathrm{CH}_{3} \mathrm{CN}\right) \subset \mathrm{V}_{12} \mathrm{O}_{32}\right]^{4-}$ was obtained. An excess amount of chloride allowed the liberated $\left[\mathrm{V}_{8} \mathrm{O}_{24}\right]^{8-}$ macrocycle to capture chloride and a subsequent

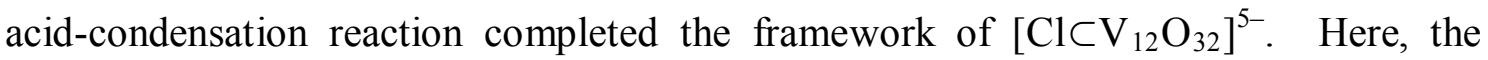
versatility of vanadium coordination chemistry is exemplified; like "umpolung" (polarity reversal) in organic chemistry, the interaction may alternate coordination from between the anionic $\mathrm{VO}_{4}$ unit and $\mathrm{Cu}^{2+}$, to the coordination between the cationic $\mathrm{V}^{5+}$ at the basal plane in square pyramidal $\mathrm{VO}_{5}$ and $\mathrm{Cl}^{-}$. The transformation of the vanadium coordination sphere between the $\mathrm{VO}_{4}$ and $\mathrm{VO}_{5}$ unit may trigger the switch of polarity from cationic to anionic templates. Attempts to remove $\mathrm{Cu}^{2+}$ by using $\mathrm{NaCN}$ were unsuccessful; the reaction produced insoluble pale-yellow precipitates that could not be identified. The example to use $\mathrm{Cu}^{2+}$ as a structure directing template was previously reported and a pentagonal secondary building units of the type $\left\{(\mathrm{V}) \mathrm{M}_{5}\right\}(\mathrm{M}=\mathrm{Cu}, \mathrm{V})$ draw a parallel with the well-known $\left\{(\mathrm{Mo}) \mathrm{Mo}_{5}\right\}$ pentagons observed in Keplerate type cluster [37].

To avoid the use of extremely toxic hydrogen cyanide gas, an alternative route was investigated for the synthesis of complex 1. The methoxo functional group in hexamethoxohexavanadates, $\left[\mathrm{V}_{6} \mathrm{O}_{13}(\mathrm{OMe})_{6}\right]^{2-}$, is susceptible to hydrolysis. In functionalized hexavanadates, the reduced form is stable, allowing investigation of the 
magnetic interactions in hexavanadate cores [38-42]. In the highest oxidation state of $\mathrm{V}(\mathrm{V})$ polyoxovanadates, stable hexamethoxo-hexavanadates can be obtained easily for use as starting materials. Thus, it was utilized for the synthesis of 1 via controlled hydrolysis. Isopropanol stock solution that contained 3 equivalents of water was added dropwise to a dichloromethane solution of the hexavanadate to produces $\mathbf{1}$ in reasonable yield by hydrolysis with the chloride template. Here, the alkoxide group on the hexavanadate was transformed to an oxo-bridged species by hydrolysis.

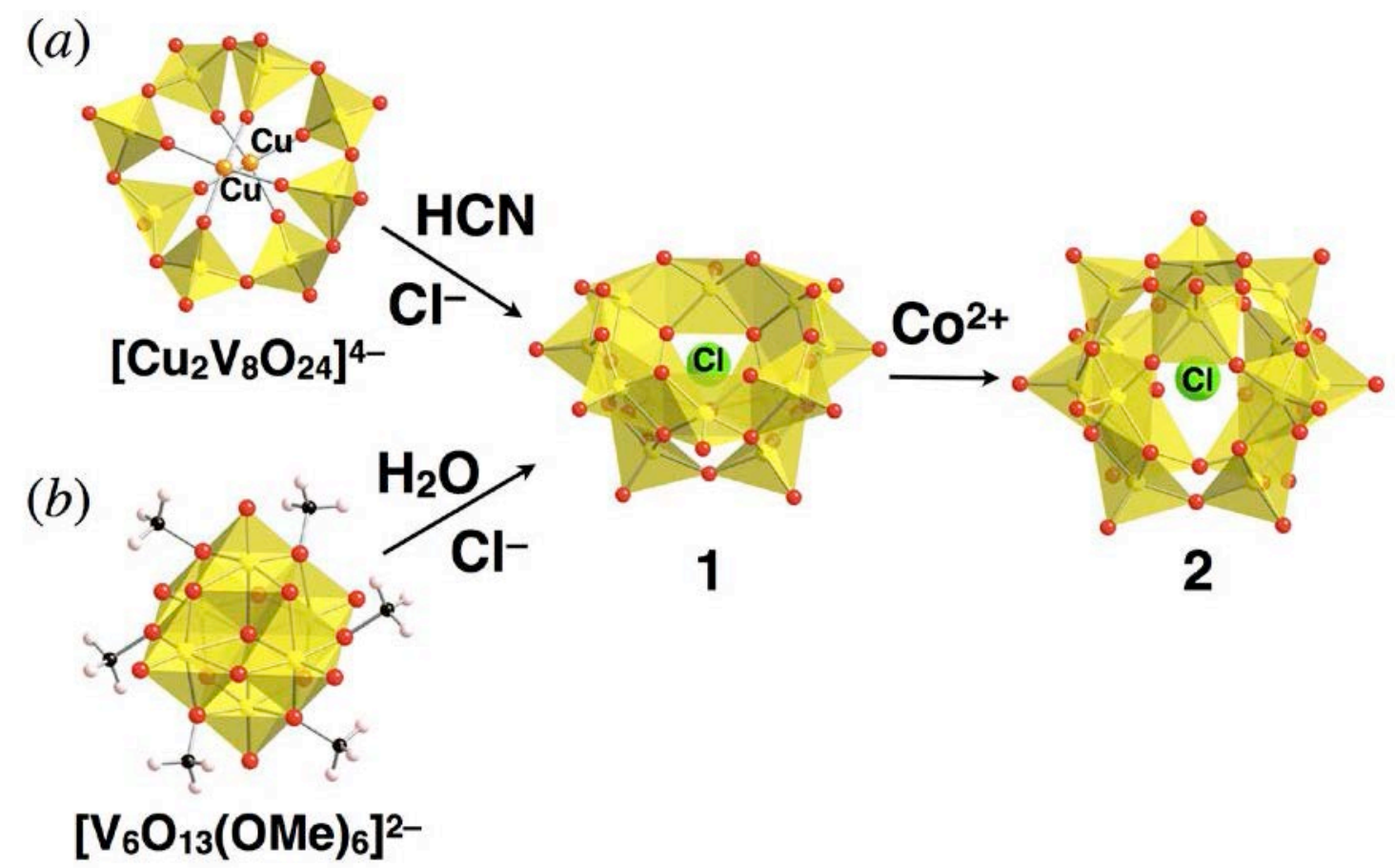

Scheme 1. Synthesis of 2 using methods $(a)$ and $(b)$. The polyoxometalates are depicted as a combination of polyhedra and ball-and-stick models $\left(\mathrm{VO}_{x}\right.$ units: yellow polyhedra; C: black; $\mathrm{Cl}$ : green; $\mathrm{Cu}$ : orange; $\mathrm{H}$ : white; $\mathrm{O}$ : red). 


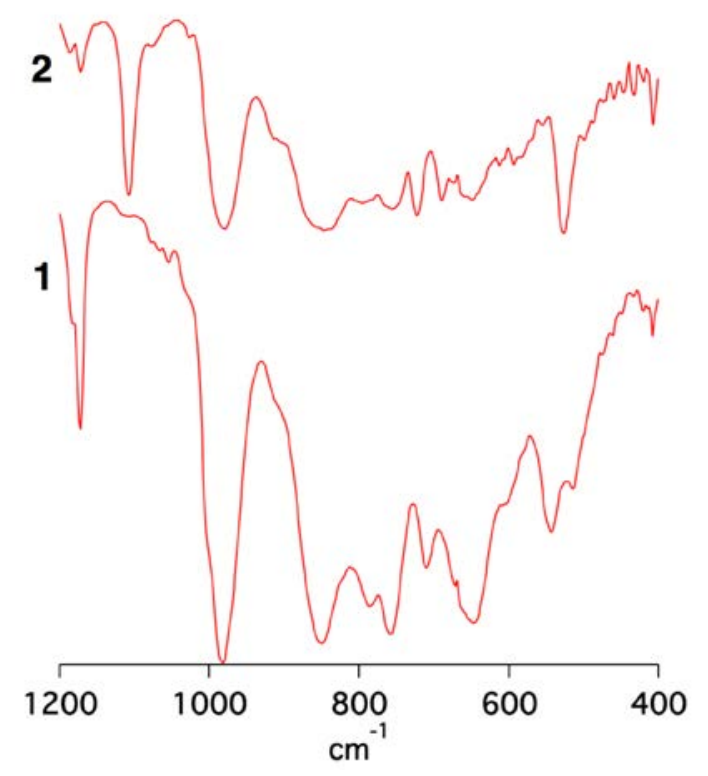

Fig. 1. IR spectra of 1 and 2.

The acetonitrile-incorporated "Klemperer" type bowl-shaped dodecavanadate, $\left[\mathrm{CH}_{3} \mathrm{CN} \subset \mathrm{V}_{12} \mathrm{O}_{32}\right]^{4-}$ has an open bowl structure with no structural restriction to the dissociation of the acetonitrile. However, dissociation of chloride in $\mathbf{1}$ was not observed and the formation reaction of $\mathbf{1}$ was irreversible [9]. The chloride guest was attached firmly in the cavity and could be dissociated only upon heating to the acetonitrile boiling point, when the solvent itself acted as a guest molecule in excess. In fact, only chloride incorporated species were observed in ESI spectrum, and the peaks based on $\left[\mathrm{CH}_{3} \mathrm{CN} \subset \mathrm{V}_{12} \mathrm{O}_{32}\right]^{4-}$ were not observed despite the fact that is readily observable species in ESI spectrum (Fig. S2 and Table S2). To physically contain the chloride anion, even in acetonitrile, a capping reaction of the bowl was designed to form a ball-shaped molecule. In the presence of protic acids such as water, complex $\mathbf{1}$ was isomerized to $\left[\mathrm{HV}_{12} \mathrm{O}_{32}(\mathrm{Cl})\right]^{4-}[20]$. Thus the amount of water must be minimized to prevent isomerization that complicates the mixture of products. Instead of a protic acid, a nonprotic Lewis acid was used to facilitate the reaction. Cobalt(II) salts were effective for the capping reaction. The reaction of 1 with a Lewis acid such as $\mathrm{Co}\left(\mathrm{NO}_{3}\right)_{2}, \mathrm{TiCl}_{4}$ or $\mathrm{CuCl}_{2}$ in acetonitrile produced complex 2. The addition of excess $\left(\mathrm{C}_{2} \mathrm{H}_{5}\right)_{4} \mathrm{NCl}$ to the mixture of $\mathrm{Co}^{2+}$ and cluster 1 gave brown precipitates after 2 days. The green color of the upper layer of the solution suggested that cobalt cations remained in the solution. The 
precipitates were hardly soluble in acetonitrile. However, addition of $\mathrm{Ph}_{4} \mathrm{PBr}$ redissolved the precipitate, which was recrystallized as a mixed salt of $\mathrm{Et}_{4} \mathrm{~N}^{+}$and $\mathrm{Ph}_{4} \mathrm{P}^{+}$. The $\left(\mathrm{n}-\mathrm{Et}_{4} \mathrm{~N}\right)_{2}\left(\left(\mathrm{C}_{6} \mathrm{H}_{5}\right)_{4} \mathrm{P}\right)_{3}\left[\mathrm{H}_{2} \mathrm{~V}_{14} \mathrm{O}_{38}(\mathrm{Cl})\right]$ crystals were red-brown in color. Without the addition of a Lewis acid, no reaction occurred in acetonitrile. By utilizing the starting material in method (b), 2 was synthesized directly without the isolation of the intermediate 1. The reaction between $\left[\mathrm{V}_{6} \mathrm{O}_{13}(\mathrm{OMe})_{6}\right]^{2-}$ and $\mathrm{ZrOCl}_{2} \cdot 8 \mathrm{H}_{2} \mathrm{O}$ afforded $\left(\mathrm{Et}_{4} \mathrm{~N}\right)_{5}\left[\mathrm{H}_{2} \mathrm{~V}_{14} \mathrm{O}_{38}(\mathrm{Cl})\right](2 a)$ from a one-pot synthesis. The zirconium salt functions in three ways in this reaction: it provides a source of water for hydrolysis, acts as a source for the chloride template, and acts as a Lewis acid to facilitate the capping reaction in situ. This direct synthesis produced a tetraethyl ammonium salt, which provided better crystal quality for X-ray crystallographic analysis. Complexes $\mathbf{1}$ and $\mathbf{2}$ were brown in color and did not produce characteristic peaks in the UV spectra (Fig. S3). The yellow-to-brown feature in the spectra is typical for $\mathrm{V}^{\mathrm{V}}$ polyoxovanadate complexes. Cyclicvoltammetry of 2 in DMSO showed one reversible wave at $-486 \mathrm{mV}\left(\mathrm{E}_{1 / 2}\right) \mathrm{vs} \mathrm{Fc} / \mathrm{Fc}^{+}$and one quasi-reversible wave at $-1089 \mathrm{mV}\left(\mathrm{E}_{1 / 2}\right) \mathrm{vs} \mathrm{Fc} / \mathrm{Fc}^{+}\left(\mathrm{E}_{\mathrm{pa}}\right.$ at $-1281 \mathrm{mV}$ and $\mathrm{E}_{\mathrm{pc}}$ at -922 $\mathrm{mV}$ ) (Fig. S4). In reduced spherical polyoxovanadates, observation of multiple reversible redoxes is typical because vanadium is a redox-active element [43]. But for 2 , the presence of labile protons might disturb the multiple reversible redox reactions. In these inorganic complexes without the presence of an organic ligand, the IR spectra were able to show structure-specific patterns due to the $\mathrm{M}-\mathrm{O}$ stretching of polyoxometalates because no organic fingerprint stretching overlapped in this region. The IR spectra of complexes 1 and 2 contained one $\mathrm{V}=\mathrm{O}$ stretching near $990 \mathrm{~cm}^{-1}$ and a series of $\mathrm{V}-\mathrm{O}$ bridging stretches in the range of $920-400 \mathrm{~cm}^{-1}$ (Fig. 1). The similarities of the IR spectra of 1 and 2 suggested that the two complexes contained comparable structures. In fact, the structure of spherical tetradecavanadate $\left[\mathrm{V}_{14} \mathrm{O}_{38}(\mathrm{Cl})\right]^{7-}$ is similar to the structure of $\mathbf{1}$ with two missing $\mathrm{V}=\mathrm{O}$ units from the rim of the $\mathrm{V}_{12}$ bowl in $\mathbf{1}$.

\subsection{Structural description}

Single crystal X-ray crystallography revealed a spherical V14 cage with a chloride guest at the center (Fig. 2). For comparison, the structure of $\mathbf{2 a}$ is described in relation to the structure of $\mathbf{1}$; i.e., by adding a $\left[\mathrm{V}_{4} \mathrm{O}_{8}\right]^{4+}$ capping group on top of $\mathbf{1}$ with two $[\mathrm{V}=\mathrm{O}]^{3+}$ 
groups missing from the rim. Thus, 2a consists of three layers: the bottom unit $\left(\left[\mathrm{V}_{4} \mathrm{O}_{8}\right]^{4+}\right)$, the middle cyclic unit $\left(\left[\mathrm{V}_{6} \mathrm{O}_{22}\right]^{14}\right)$ with two missing $\mathrm{V}=\mathrm{O}$ groups from the original bowl rim, and the capping unit $\left(\left[\mathrm{V}_{4} \mathrm{O}_{8}\right]^{4+}\right)$. The lacunary positions were disordered over four sites in occupancy of halvs. The charge balance consideration suggested a protonation of the core, and BVS calculations indicated that protonation occurred at the two oxygen atoms on the lacunary sites [44]. Protonation at the two oxygen sites had BVS values of 1.47 and 1.51, while the remaining oxygen atoms had values in the range of 1.84 to 2.44 . The orientation of the $\left[\mathrm{V}_{4} \mathrm{O}_{8}\right]^{4+}$ square units at the bottom and the top were twisted $45^{\circ}$. The distances between chloride and vanadium atoms were in the range of $3.555(2)$ to $3.622(2) \AA$. The narrow range of the $\mathrm{V} \cdots \mathrm{Cl}$ distances reflects the highly symmetric cage of the tetradecavanadate cluster core. The longer distances as compared to $\left[\mathrm{HV}_{12} \mathrm{O}_{32} \mathrm{Cl}\right]^{4-}(3.22-3.49 \AA)$ suggested that the cluster sphere is larger due to the increased number of vanadium atoms.

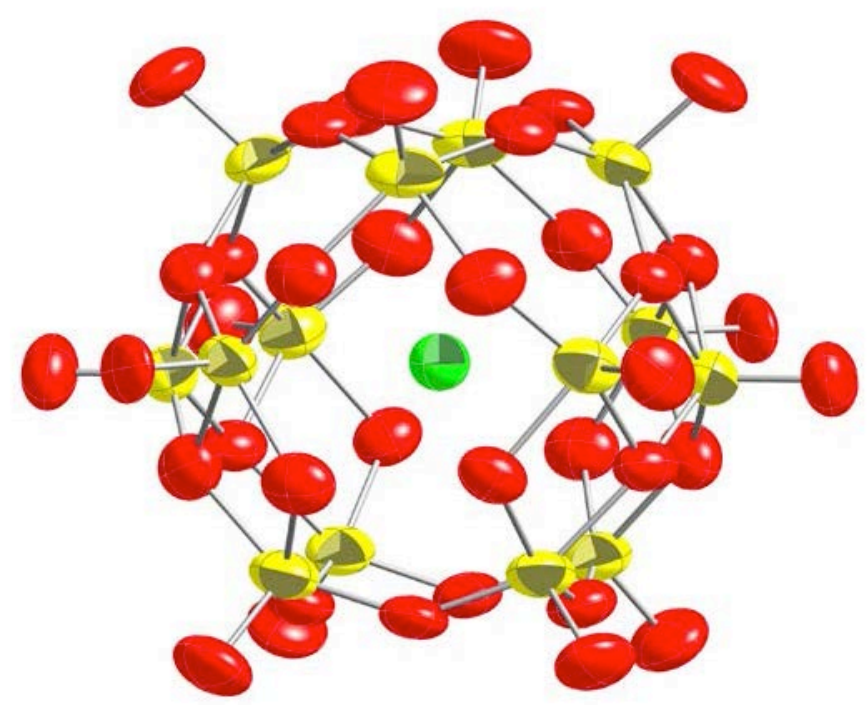

Fig. 2. ORTEP view of $\mathbf{2 a}$ with thermal ellipsoids drawn at the $50 \%$ probability level. Vanadium, chlorine, and oxygen atoms are represented by yellow equatorial octant, green equatorial octant, and red ellipsoids, respectively. Disordered VO groups are omitted for clarity. 


\section{3. ${ }^{51}$ V NMR and ESI mass spectroscopy in acetonitrile solution}

The ${ }^{51} \mathrm{~V}$ NMR spectrum of $\mathbf{2}$ in acetonitrile contained four well-resolved peaks at $547,-567,-579$ and $-592 \mathrm{ppm}$ with an intensity ratio of 1:1:3:2 (Fig. 3). Five chemical environments were expected for cluster 2 in the ratio of 1:1:1:2:2 (Fig. S5). Thus, the peak at $-579 \mathrm{ppm}$ with the intensity of $3 \mathrm{~V}$ is assumed to be two overlapping peaks with a 1:2 ratio. This overlap could be partly resolved by increasing the solution temperature to $70^{\circ} \mathrm{C}$; the split at high temperature coincided with the number and ratio of chemical environments of the solid-state structure. When the hot solution was cooled back to room temperature, the original signals appeared again in the spectrum. No dynamic behavior of the cluster core was observed in this temperature range. Detailed assignments based on the $2 \mathrm{D}{ }^{51} \mathrm{~V}$ NMR is shown in Fig. S5.

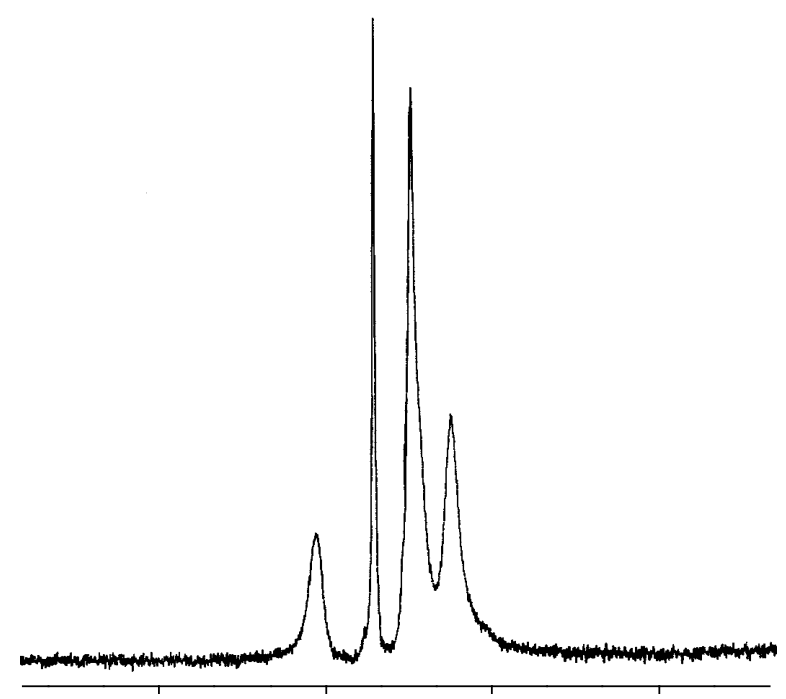

Fig. $3 .{ }^{51} \mathrm{~V}$ NMR of $\mathbf{2}$ in acetonitrile at room temperature.

The ESI mass spectrum of cluster 2 in acetonitrile is shown in Fig. 4. The peaks were successfully assigned based on the related species from complex 2. Most of the observed peaks were solvated with acetonitrile. The cluster anions, $\left[\mathrm{H}_{2} \mathrm{~V}_{14} \mathrm{O}_{38}(\mathrm{Cl})\right]^{5-}$ were observed in peaks (peak Nos. 20-23 in Fig. 4) without accompanying cations with a different number of solvated acetonitriles. In addition, the peaks associated with different combinations of $\mathrm{Et}_{4} \mathrm{~N}^{+}$cation and $\mathrm{Ph}_{4} \mathrm{P}^{+}$along with different levels of protonation were 
observed with the cluster core. The assignments are compiled in Table 2. 


\section{Table 2}

ESI mass spectrum assignments for $\mathbf{2}$ in acetonitrile. Peak numbers correspond to those in Fig. 4.

Peak number Ionic species $\quad \mathrm{m} / \mathrm{z}$

\begin{tabular}{|c|c|c|}
\hline 1 & $\left\{\left[\left(\mathrm{C}_{6} \mathrm{H}_{5}\right)_{4} \mathrm{P}\right]_{2}\left[\mathrm{~V}_{14} \mathrm{O}_{38} \mathrm{Cl}\right]\right\}^{3-}$ & 678.0 \\
\hline 2 & $\left\{\left[\left(\mathrm{C}_{6} \mathrm{H}_{5}\right)_{4} \mathrm{P}\right]\left[\left(\mathrm{C}_{2} \mathrm{H}_{5}\right)_{4} \mathrm{~N}\right]\left[\mathrm{V}_{14} \mathrm{O}_{38} \mathrm{Cl}\right]\left(\mathrm{CH}_{3} \mathrm{CN}\right)_{3}\right\}^{3-}$ & 649.4 \\
\hline 3 & $\left\{\left[\left(\mathrm{C}_{6} \mathrm{H}_{5}\right)_{4} \mathrm{P}\right]\left[\left(\mathrm{C}_{2} \mathrm{H}_{5}\right)_{4} \mathrm{~N}\right]\left[\mathrm{V}_{14} \mathrm{O}_{38} \mathrm{Cl}\right]\left(\mathrm{CH}_{3} \mathrm{CN}\right)_{2}\right\}^{3-}$ & 635.8 \\
\hline 4 & $\left\{\left[\left(\mathrm{C}_{6} \mathrm{H}_{5}\right)_{4} \mathrm{P}\right]\left[\left(\mathrm{C}_{2} \mathrm{H}_{5}\right)_{4} \mathrm{~N}\right]\left[\mathrm{V}_{14} \mathrm{O}_{38} \mathrm{Cl}\right]\left(\mathrm{CH}_{3} \mathrm{CN}\right)\right\}^{3-}$ & 622.1 \\
\hline 5 & $\left\{\left[\left(\mathrm{C}_{2} \mathrm{H}_{5}\right)_{4} \mathrm{~N}\right]_{2}\left[\mathrm{~V}_{14} \mathrm{O}_{38} \mathrm{Cl}\right]\left(\mathrm{CH}_{3} \mathrm{CN}\right)_{3}\right\}^{3-}$ & 579.9 \\
\hline 6 & $\left\{\left[\left(\mathrm{C}_{2} \mathrm{H}_{5}\right)_{4} \mathrm{~N}\right]_{2}\left[\mathrm{H}_{2} \mathrm{~V}_{14} \mathrm{O}_{38} \mathrm{Cl}\right]\left(\mathrm{CH}_{3} \mathrm{CN}\right)_{2}\right\}^{3-}$ & 566.9 \\
\hline 7 & $\left\{\left[\left(\mathrm{C}_{2} \mathrm{H}_{5}\right)_{4} \mathrm{~N}\right]_{2}\left[\mathrm{~V}_{14} \mathrm{O}_{38} \mathrm{Cl}\right]\left(\mathrm{CH}_{3} \mathrm{CN}\right)_{2}\right\}^{3-}$ & 566.3 \\
\hline 8 & $\left\{\left[\left(\mathrm{C}_{2} \mathrm{H}_{5}\right)_{4} \mathrm{~N}\right]_{2}\left[\mathrm{H}_{2} \mathrm{~V}_{14} \mathrm{O}_{38} \mathrm{Cl}\right]\left(\mathrm{CH}_{3} \mathrm{CN}\right)\right\}^{3-}$ & 553.2 \\
\hline 9 & $\left\{\left[\left(\mathrm{C}_{2} \mathrm{H}_{5}\right)_{4} \mathrm{~N}\right]_{2}\left[\mathrm{HV}_{14} \mathrm{O}_{38} \mathrm{Cl}\right]\left(\mathrm{CH}_{3} \mathrm{CN}\right)\right\}^{3-}$ & 552.6 \\
\hline 10 & $\left\{\left[\left(\mathrm{C}_{2} \mathrm{H}_{5}\right)_{4} \mathrm{~N}\right]_{2}\left[\mathrm{H}_{2} \mathrm{~V}_{14} \mathrm{O}_{38} \mathrm{Cl}\right]\right\}^{3-}$ & 539.0 \\
\hline 11 & $\left\{\left[\left(\mathrm{C}_{2} \mathrm{H}_{5}\right)_{4} \mathrm{~N}\right]_{2}\left[\mathrm{HV}_{14} \mathrm{O}_{38} \mathrm{Cl}\right]\right\}^{3-}$ & 538.6 \\
\hline 12 & $\left\{\left[\left(\mathrm{C}_{6} \mathrm{H}_{5}\right)_{4} \mathrm{P}\right]\left[\mathrm{HV}_{14} \mathrm{O}_{38} \mathrm{Cl}\right]\left(\mathrm{CH}_{3} \mathrm{CN}\right)_{4}\right\}^{4-}$ & 465.0 \\
\hline 13 & $\left\{\left[\left(\mathrm{C}_{6} \mathrm{H}_{5}\right)_{4} \mathrm{P}\right]\left[\mathrm{HV}_{14} \mathrm{O}_{38} \mathrm{Cl}\right]\left(\mathrm{CH}_{3} \mathrm{CN}\right)_{3}\right\}^{4-}$ & 454.7 \\
\hline 14 & $\left\{\left[\left(\mathrm{C}_{2} \mathrm{H}_{5}\right)_{4} \mathrm{~N}\right]\left[\mathrm{HV}_{14} \mathrm{O}_{38} \mathrm{Cl}\right]\left(\mathrm{CH}_{3} \mathrm{CN}\right)_{7}\right\}^{4-}$ & 443.6 \\
\hline 15 & $\left\{\left[\left(\mathrm{C}_{2} \mathrm{H}_{5}\right)_{4} \mathrm{~N}\right]\left[\mathrm{HV}_{14} \mathrm{O}_{38} \mathrm{Cl}\right]\left(\mathrm{CH}_{3} \mathrm{CN}\right)_{6}\right\}^{4-}$ & 433.3 \\
\hline 16 & $\left\{\left[\left(\mathrm{C}_{2} \mathrm{H}_{5}\right)_{4} \mathrm{~N}\right]\left[\mathrm{HV}_{14} \mathrm{O}_{38} \mathrm{Cl}\right]\left(\mathrm{CH}_{3} \mathrm{CN}\right)_{5}\right\}^{4-}$ & 423.1 \\
\hline 17 & $\left\{\left[\left(\mathrm{C}_{2} \mathrm{H}_{5}\right)_{4} \mathrm{~N}\right]\left[\mathrm{HV}_{14} \mathrm{O}_{38} \mathrm{Cl}\right]\left(\mathrm{CH}_{3} \mathrm{CN}\right)_{4}\right\}^{4-}$ & 412.9 \\
\hline 18 & $\left\{\left[\left(\mathrm{C}_{2} \mathrm{H}_{5}\right)_{4} \mathrm{~N}\right]\left[\mathrm{HV}_{14} \mathrm{O}_{38} \mathrm{Cl}\right]\left(\mathrm{CH}_{3} \mathrm{CN}\right)_{3}\right\}^{4-}$ & 402.6 \\
\hline 19 & $\left\{\left[\left(\mathrm{C}_{2} \mathrm{H}_{5}\right)_{4} \mathrm{~N}\right]\left[\mathrm{HV}_{14} \mathrm{O}_{38} \mathrm{Cl}\right]\left(\mathrm{CH}_{3} \mathrm{CN}\right)_{2}\right\}^{4-}$ & 392.4 \\
\hline 20 & $\left\{\left[\mathrm{H}_{2} \mathrm{~V}_{14} \mathrm{O}_{38} \mathrm{Cl}\right]\left(\mathrm{CH}_{3} \mathrm{CN}\right)_{10}\right\}^{5-}$ & 353.6 \\
\hline 21 & $\left\{\left[\mathrm{H}_{2} \mathrm{~V}_{14} \mathrm{O}_{38} \mathrm{Cl}\right]\left(\mathrm{CH}_{3} \mathrm{CN}\right)_{9}\right\}^{5-}$ & 345.4 \\
\hline 22 & $\left\{\left[\mathrm{H}_{2} \mathrm{~V}_{14} \mathrm{O}_{38} \mathrm{Cl}\right]\left(\mathrm{CH}_{3} \mathrm{CN}\right)_{8}\right\}^{5-}$ & 337.2 \\
\hline 23 & $\left\{\left[\mathrm{H}_{2} \mathrm{~V}_{14} \mathrm{O}_{38} \mathrm{Cl}\right]\left(\mathrm{CH}_{3} \mathrm{CN}\right)_{7}\right\}^{5-}$ & 329.0 \\
\hline
\end{tabular}




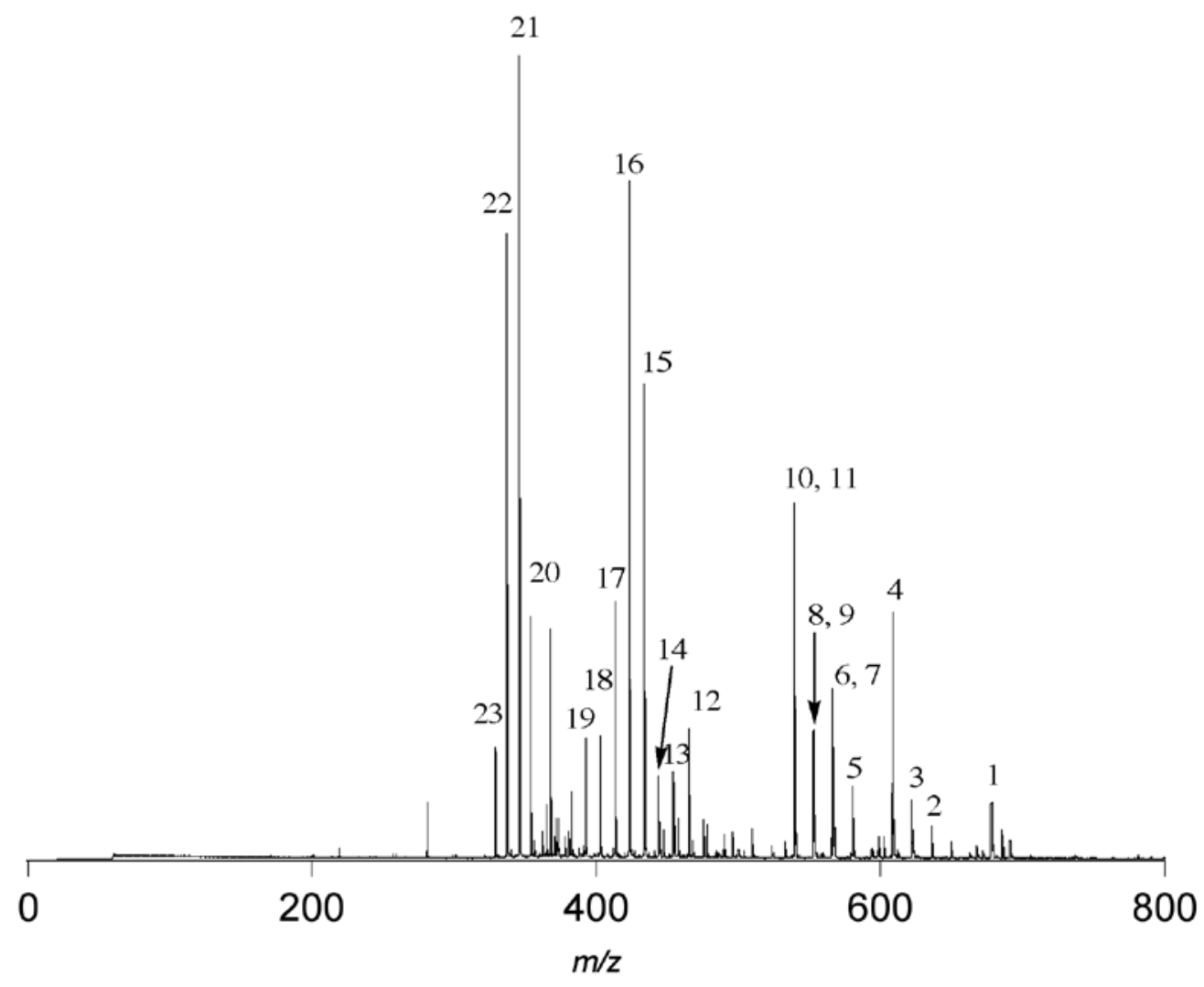

Fig. 4. ESI spectrum of 2 in acetonitrile.

\section{Conclusions}

A synthesis of a spherical anion, from a bowl- to a ball-type framework, was developed. In this synthetic approach, a template anion was incorporated rationally to assemble the spherical cage. All V(V) oxidation state spherical polyoxovanadates were characterized by single-crystal X-ray crystallography, FT-IR spectroscopy, ${ }^{51} \mathrm{~V}$ NMR and ESI mass spectroscopy. The structural transformation from a disk-shaped copper complex, through a bowl-shaped dodecavanadate with a chloride anion guest, to a ball-type tetradecavanadates, demonstrated the feasibility of a synthetic path for constructing spherical supermolecules. Template switching from a cation to an anion template was a noteworthy feature in the versatile vanadium cluster host complexes. 


\section{Acknowledgement}

We thank the Ministry of Education, Culture, Sports, Science and Technology, Japan for a Grant-in-Aid for Scientific Research (MEXT KAKENHI Grant Number 23550069).

\section{Appendix A. Supplementary material}

CCDC 961386 contains the supplementary crystallographic data for 2 . The data can be obtained free of charge from the Cambridge Crystallographic Data Center via www.ccdc.cam.ac.uk/data request/cif. The ESI mass spectra (Fig. S1 and S2) and the assignments (Table S1 and S2), UV spectrum (Fig. S3), Cyclic voltammogram (Fig. S4) and the ${ }^{51} \mathrm{~V}$ COSY NMR (Fig. S5) have been provided in the supplementary material. Supplementary data associated with this article can be found, in the online version, at http://dx.doi.org//. 


\section{References}

[1] (a) L. Cronin, A. Müller, Chem. Soc. Rev. 41 (2012) 7333;

[2] P. C. H. Mitchell, Nature, 348 (1990) 15.

[3] A. Müller, Nature, 352 (1991) 115.

[4] M. T. Pope, Nature, 355 (1992) 27.

[5] A. Müller, D. Rehder, E. T. K. Haupt, A. Merca, H. Bögge, M. Schmidtmann, G. Heinze-Bruckner, Angew. Chem., Int. Ed. 43 (2004) 5115.

[6] A. Müller, L. Toma, H. Bögge, C. Schaeffer, A. Stammler, Angew. Chem., Int. Ed. 44 (2005) 7757.

[7] L. Cronin, Angew. Chem., Int. Ed. 45 (2006) 3576.

[8] D. Rehder, T. K. Haupt Erhard, A. Müller, Magn. Reson. Chem. 46, Suppl. 1 (2008) S24.

[9] T. Kurata, Y. Hayashi, K. Isobe, Chem. Lett. 39 (2010) 708.

[10] V.W. Day, W.G. Klemperer, O.M. Yaghi, J. Am. Chem. Soc. 111 (1989) 5959.

[11] W.G. Klemperer, T.A. Marquart, O.M. Yaghi, Mater. Chem. Phys. 29 (1991) 97.

[12] N. Kawanami, T. Ozeki, A. Yagasaki, J. Am. Chem. Soc. 122 (2000) 1239.

[13] M.-M. Rohmer, J. Devemy, R. Wiest, M. Bénard, J. Am. Chem. Soc. 118 (1996) 13007.

[14] M.-M. Rohmer, M. Bénard, J.-P. Blaudeau, J.-M. Maestre, J.-M. Poblet, Coord. Chem. Rev. 178-180 (1998) 1019.

[15] A. Müller, H. Reuter, S. Dillinger, Angew. Chem., Int. Ed. Engl. 34 (1995) 2328.

[16] A. Müller, F. Peters, M.T. Pope, D. Gatteschi, Chem. Rev. 98 (1998) 239.

[17] L. Cronin, Compr. Coord. Chem. II 7 (2004) 1.

[18] Y. Koyama, Y. Hayashi, K. Isobe, Chem. Lett. 37 (2008) 578.

[19] T.D. Keene, D.M. D'Alessandro, K.W. Kramer, J.R. Price, D.J. Price, S. Decurtins, C.J. Kepert, Inorg. Chem. 51 (2012) 9192.

[20] K. Okaya, T. Kobayashi, Y. Koyama, Y. Hayashi, K. Isobe, Eur. J. Inorg. Chem. (2009) 5156.

[21] Q. Chen, J. Zubieta, J. Chem. Soc., Chem. Commun. (1994) 1635.

[22] S. Konar, A. Clearfield, Inorg. Chem. 47 (2008) 3492.

[23] J.M. Breen, W. Schmitt, Angew. Chem., Int. Ed. 47 (2008) 6904.

[24] M. Breen John, L. Zhang, R. Clement, W. Schmitt, Inorg Chem, 51 (2012) 19. 
[25] J.M. Breen, R. Clerac, L. Zhang, S.M. Cloonan, E. Kennedy, M. Feeney, T. McCabe, D.C. Williams, W. Schmitt, Dalton Trans. 41 (2012) 2918.

[26] Y. Hayashi, Coord. Chem. Rev. 255 (2011) 2270.

[27] T. Kurata, Y. Hayashi, K. Isobe, Chem. Lett. 38 (2009) 218.

[28] S. Inami, M. Nishio, Y. Hayashi, K. Isobe, H. Kameda, T. Shimoda, Eur. J. Inorg. Chem. (2009) 5253.

[29] M. Nishio, S. Inami, M. Katayama, K. Ozutsumi, Y. Hayashi, Inorg. Chem. 51 (2012) 784.

[30] M. Nishio, S. Inami, Y. Hayashi, Eur. J. Inorg. Chem. 2013 (2013) 1876.

[31] T. Kurata, A. Uehara, Y. Hayashi, K. Isobe, Inorg. Chem. 44 (2005) 2524.

[32] K. Domae, D. Uchimura, Y. Koyama, S. Inami, Y. Hayashi, K. Isobe, H. Kameda, T. Shimoda, Pure Appl. Chem. 81 (2009) 1323.

[33] R. D. Pike, Organomettalics, 31 (2012) 7647.

[34] G. M. Sheldrick, Acta Crystallogr., Sect. A: Fundam. Crystallogr. 64 (2008) 112.

[35] A. L. Spek, PLATON, Utrecht University, Utrecht, NL, 2005.

[36] N.F. Curtis, Coord. Chem. Rev. 3 (1968) 3.

[37] J. Foster, B. Rösner, R. H. Fink, L. C. Nye, I. I-Burmazovic, K. Kastner, J. Tucher, C. Streb, Chem. Sci. 4 (2013) 418.

[38] C. Daniel, H. Hartl, J. Am. Chem. Soc. 127 (2005) 13978.

[39] C. Aronica, G. Chastanet, E. Zueva, A. Borshch Serguei, M. Clemente-Juan Juan, D. Luneau, J. Am. Chem. Soc. 130 (2008) 2365.

[40] M. A. Augustyniak-Jablokow, C. Daniel, H. Hartl, J. Spandl, Y. V. Yablokov, Inorg. Chem. 47 (2008) 322.

[41] L. J. Batchelor, R. Shaw, S. J. Markey, M. Helliwell, E. J. L. McInnes, Chem. Eur. J. $16(2010) 5554$.

[42] A. Adach, M. Daszkiewicz, M. C-Golonka, Polyhedron, 47 (2012) 104.

[43] N. Kato, Y. Hayashi, Dalton Trans. 42 (2013) 11804.

[44] I. D. Brown, The Chemical Bond in Inorganic Chemistry, Oxford University Press, 2002. 


\section{Supplementary material}

\section{Structural conversion from bowl- to ball-type polyoxovanadates: Synthesis of a spherical tetradecavanadate through a chloride-incorporated bowl-type dodecavanadate}

Tetsuhiro Kobayashi, Sho Kuwajima, Taisei Kurata and Yoshihito Hayashi*

Department of Chemistry, Kanazawa University, Kakuma, 920-1192, Japan

*Corresponding author. Tel.: +81 762645695.

E-mail: hayashi@se.kanazawa-u.ac.jp 


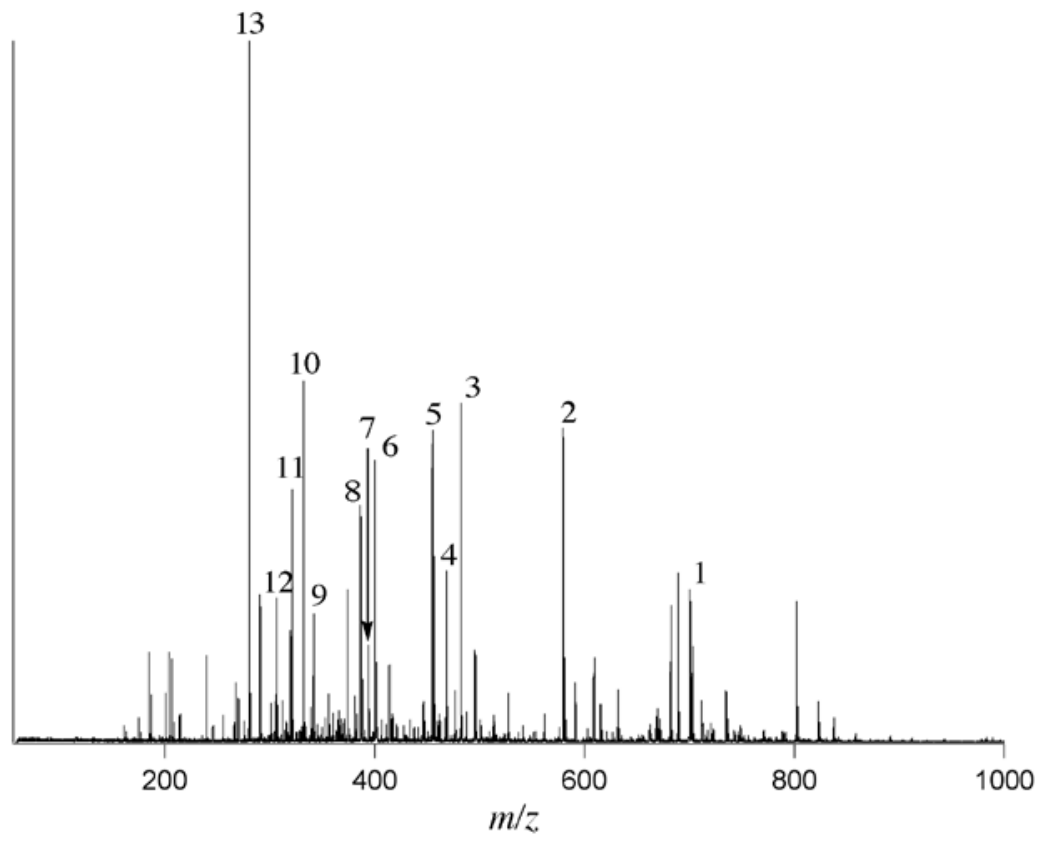

Fig. S1. ESI spectra of acetonitrile solution of $\left(\left(n-\mathrm{C}_{4} \mathrm{H}_{9}\right)_{4} \mathrm{~N}\right)_{4}\left[\mathrm{Cu}_{2} \mathrm{~V}_{8} \mathrm{O}_{24}\right]$ after exposure to hydrogen cyanide gas. Peak assignments are compiled in Table S1. 


\section{Table S1}

ESI mass spectrum assignments in Fig. S1. Peak numbers corresponds to those in Fig. S1.

\begin{tabular}{|c|c|c|}
\hline Peak number & ionic species & $\mathrm{m} / \mathrm{z}$ \\
\hline 1 & $\left\{\left[\left(\mathrm{C}_{4} \mathrm{H}_{9}\right)_{4} \mathrm{~N}\right]_{2}\left[\mathrm{Cu}_{2} \mathrm{~V}_{8} \mathrm{O}_{24}\right]\right\}^{2-}$ & 700.8 \\
\hline 2 & $\left\{\left[\left(\mathrm{C}_{4} \mathrm{H}_{9}\right)_{4} \mathrm{~N}\right] \mathrm{H}\left[\mathrm{Cu}_{2} \mathrm{~V}_{8} \mathrm{O}_{24}\right]\right\}^{2-}$ & 579.8 \\
\hline 3 & $\left\{\left[\left(\mathrm{C}_{4} \mathrm{H}_{9}\right)_{4} \mathrm{~N}\right]\left[\mathrm{V}_{12} \mathrm{O}_{32}\right]\left(\mathrm{CH}_{3} \mathrm{CN}\right)_{2}\right\}^{3-}$ & 482.3 \\
\hline 4 & $\left\{\left[\left(\mathrm{C}_{4} \mathrm{H}_{9}\right)_{4} \mathrm{~N}\right]\left[\mathrm{V}_{12} \mathrm{O}_{32}\right]\left(\mathrm{CH}_{3} \mathrm{CN}\right)\right\}^{3-}$ & 468.6 \\
\hline 5 & $\left\{\left[\left(\mathrm{C}_{4} \mathrm{H}_{9}\right)_{4} \mathrm{~N}\right]\left[\mathrm{V}_{12} \mathrm{O}_{32}\right]\right\}^{3-}$ & 454.9 \\
\hline 6 & $\left\{\left[\left(\mathrm{C}_{4} \mathrm{H}_{9}\right)_{4} \mathrm{~N}\right]\left[\mathrm{Cu}_{2} \mathrm{~V}_{8} \mathrm{O}_{24}\right]\left(\mathrm{CH}_{3} \mathrm{CN}\right)\right\}^{3-}$ & 400.1 \\
\hline 7 & $\left\{\left[\left(\mathrm{C}_{4} \mathrm{H}_{9}\right)_{4} \mathrm{~N}\right] \mathrm{H}_{4}\left[\mathrm{~V}_{8} \mathrm{O}_{24}\right] \mathrm{HCN}\left(\mathrm{CH}_{3} \mathrm{CN}\right)_{2}\left(\mathrm{H}_{2} \mathrm{O}\right)_{2}\right\}^{3-}$ & 394.4 \\
\hline 8 & $\left\{\left[\left(\mathrm{C}_{4} \mathrm{H}_{9}\right)_{4} \mathrm{~N}\right]\left[\mathrm{Cu}_{2} \mathrm{~V}_{8} \mathrm{O}_{24}\right]\right\}^{3-}$ & 386.4 \\
\hline 9 & $\left\{\left[\mathrm{~V}_{12} \mathrm{O}_{32}\right]\left(\mathrm{CH}_{3} \mathrm{CN}\right)_{6}\right\}^{4-}$ & 342.3 \\
\hline 10 & $\left\{\left[\mathrm{~V}_{12} \mathrm{O}_{32}\right]\left(\mathrm{CH}_{3} \mathrm{CN}\right)_{5}\right\}^{4-}$ & 332.1 \\
\hline 11 & $\left\{\left[\mathrm{~V}_{12} \mathrm{O}_{32}\right]\left(\mathrm{CH}_{3} \mathrm{CN}\right)_{4}\right\}^{4-}$ & 321.8 \\
\hline 12 & $\left\{\mathrm{H}\left[\mathrm{Cu}_{2} \mathrm{~V}_{8} \mathrm{O}_{24}\right]\right\}^{3-}$ & 306.1 \\
\hline 13 & $\left\{\left[\mathrm{~V}_{12} \mathrm{O}_{32}\right]\right\}^{4-}$ & 280.8 \\
\hline
\end{tabular}




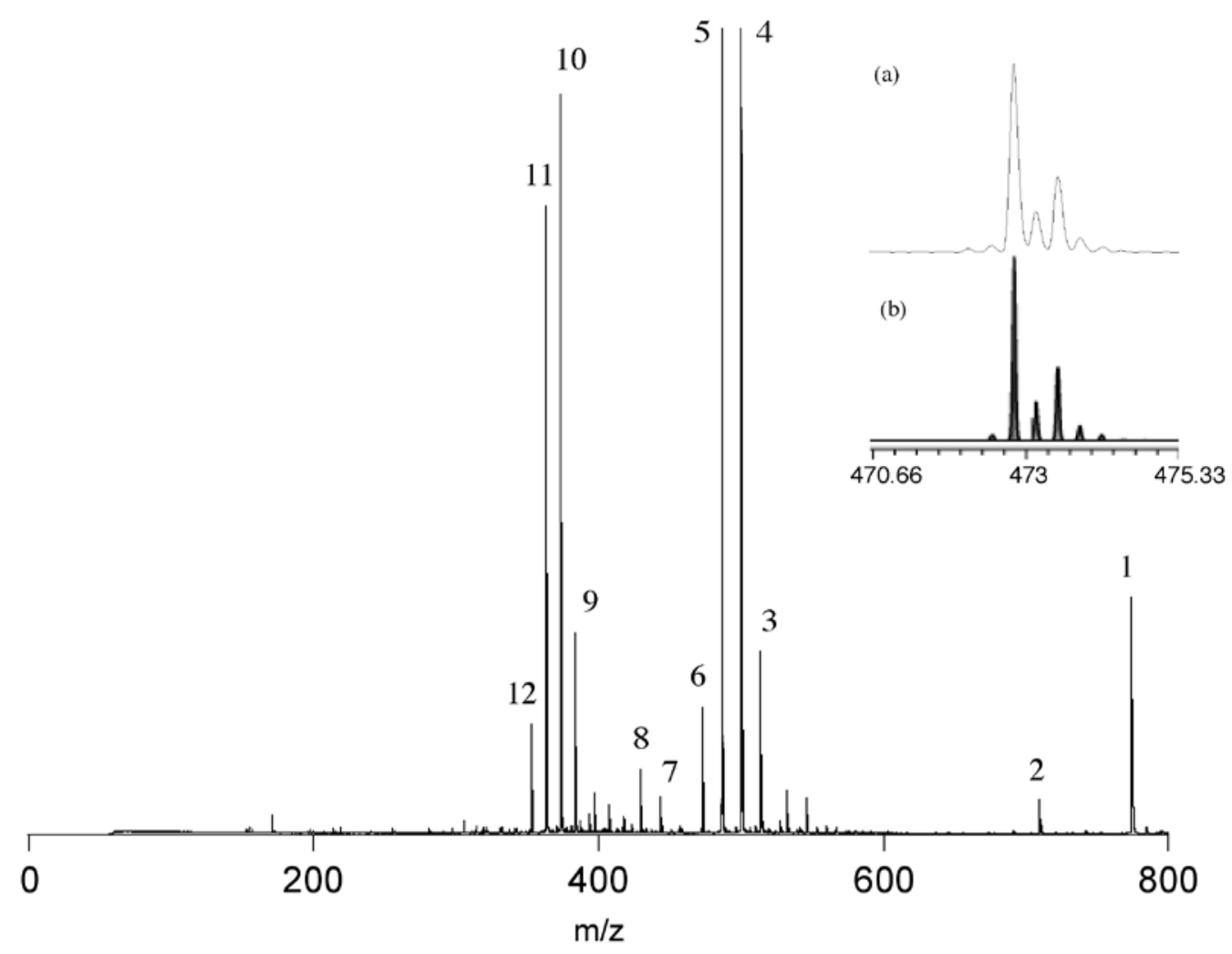

Fig. S2. ESI mass spectrum of $\mathbf{1}$ in acetonitrile solution. Peak assignments are compiled in table S2. Insets are observed (a) and simulated (b) spectra for peak no. 6.

Characteristic peak patterns based on chlorine are displayed in the insets. 


\section{Table S2}

ESI spectrum peak assignments in Fig. S2.

\begin{tabular}{lll} 
& & \\
Peak number $\quad$ ionic species $\quad \mathrm{m} / \mathrm{z}$ & \\
\hline 1 & $\left\{\left[\left(\mathrm{C}_{2} \mathrm{H}_{5}\right)_{4} \mathrm{~N}\right]_{3}\left[\mathrm{~V}_{12} \mathrm{O}_{32} \mathrm{Cl}\right]\right\}^{2-}$ & 774.4 \\
2 & $\left\{\left[\left(\mathrm{C}_{2} \mathrm{H}_{5}\right)_{4} \mathrm{~N}\right]_{2} \mathrm{H}\left[\mathrm{V}_{12} \mathrm{O}_{32} \mathrm{Cl}\right]\right\}^{2-}$ & \\
3 & $\left\{\left[\left(\mathrm{C}_{2} \mathrm{H}_{5}\right)_{4} \mathrm{~N}\right]_{2}\left[\mathrm{~V}_{12} \mathrm{O}_{32} \mathrm{Cl}\right]\left(\mathrm{CH}_{3} \mathrm{CN}\right)_{3}\right\}^{3-}$ & 513.9 \\
4 & $\left\{\left[\left(\mathrm{C}_{2} \mathrm{H}_{5}\right)_{4} \mathrm{~N}\right]_{2}\left[\mathrm{~V}_{12} \mathrm{O}_{32} \mathrm{Cl}\right]\left(\mathrm{CH}_{3} \mathrm{CN}\right)_{2}\right\}^{3-}$ & 500.2 \\
5 & $\left\{\left[\left(\mathrm{C}_{2} \mathrm{H}_{5}\right)_{4} \mathrm{~N}\right]_{2}\left[\mathrm{~V}_{12} \mathrm{O}_{32} \mathrm{Cl}\right]\left(\mathrm{CH}_{3} \mathrm{CN}\right)\right\}^{3-}$ & 486.5 \\
6 & $\left\{\left[\left(\mathrm{C}_{2} \mathrm{H}_{5}\right)_{4} \mathrm{~N}\right]_{2}\left[\mathrm{~V}_{12} \mathrm{O}_{32} \mathrm{Cl}\right]\right\}^{3-}$ & 472.8 \\
7 & $\left\{\left[\left(\mathrm{C}_{2} \mathrm{H}_{5}\right)_{4} \mathrm{~N}\right] \mathrm{H}\left[\mathrm{V}_{12} \mathrm{O}_{32} \mathrm{Cl}\right]\left(\mathrm{CH}_{3} \mathrm{CN}\right)\right\}^{3-}$ & 443.5 \\
8 & $\left\{\left[\left(\mathrm{C}_{2} \mathrm{H}_{5}\right)_{4} \mathrm{~N}\right] \mathrm{H}\left[\mathrm{V}_{12} \mathrm{O}_{32} \mathrm{Cl}\right]\right\}^{3-}$ & 429.8 \\
9 & $\left\{\left[\left(\mathrm{C}_{2} \mathrm{H}_{5}\right)_{4} \mathrm{~N}\right]\left[\mathrm{V}_{12} \mathrm{O}_{32} \mathrm{Cl}\right]\left(\mathrm{CH}_{3} \mathrm{CN}\right)_{6}\right\}^{4-}$ & 383.6 \\
10 & $\left\{\left[\left(\mathrm{C}_{2} \mathrm{H}_{5}\right)_{4} \mathrm{~N}\right]\left[\mathrm{V}_{12} \mathrm{O}_{32} \mathrm{Cl}\right]\left(\mathrm{CH}_{3} \mathrm{CN}\right)_{5}\right\}^{4-}$ & 373.4 \\
11 & $\left\{\left[\left(\mathrm{C}_{2} \mathrm{H}_{5}\right)_{4} \mathrm{~N}\right]\left[\mathrm{V}_{12} \mathrm{O}_{32} \mathrm{Cl}\right]\left(\mathrm{CH}_{3} \mathrm{CN}\right)_{4}\right\}^{4-}$ & 363.1 \\
12 & $\left\{\left[\left(\mathrm{C}_{2} \mathrm{H}_{5}\right)_{4} \mathrm{~N}\right]\left[\mathrm{V}_{12} \mathrm{O}_{32} \mathrm{Cl}\right]\left(\mathrm{CH}_{3} \mathrm{CN}\right)_{3}\right\}^{4-}$ & 352.9 \\
& & \\
& &
\end{tabular}




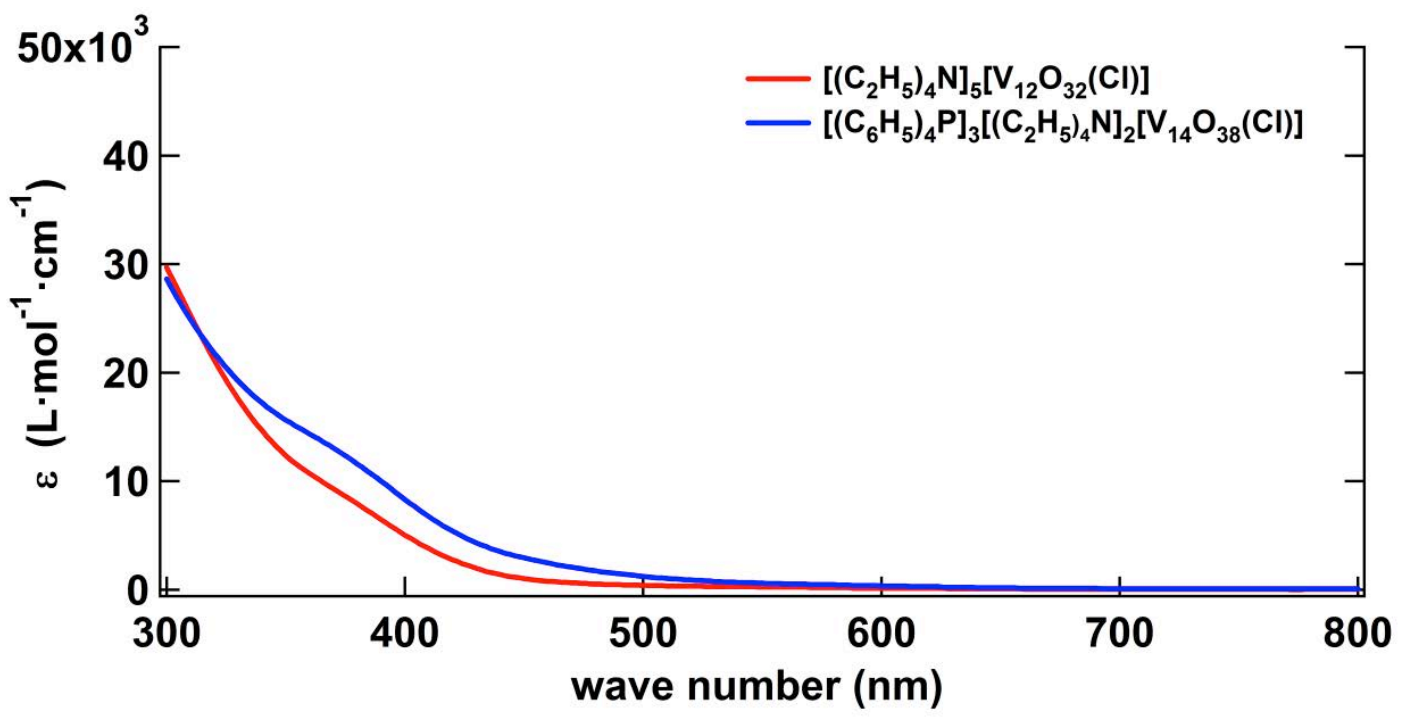

Fig. S3. UV-Vis spectra of $\left[\left(\mathrm{C}_{2} \mathrm{H}_{5}\right)_{4} \mathrm{~N}\right]_{5}\left[\mathrm{~V}_{12} \mathrm{O}_{32}(\mathrm{Cl})\right]\left(\mathbf{1}\right.$, red, $\left.2.1 \times 10^{-2} \mathrm{M}\right)$ and $\left[\left(\mathrm{C}_{6} \mathrm{H}_{5}\right)_{4} \mathrm{P}\right]_{3}\left[\left(\mathrm{C}_{2} \mathrm{H}_{5}\right)_{4} \mathrm{~N}_{2}\left[\mathrm{H}_{2} \mathrm{~V}_{14} \mathrm{O}_{38}(\mathrm{Cl})\right]\right.$ (2, blue, $\left.2.1 \times 10^{-2} \mathrm{M}\right)$ in DMSO. The shoulders of 1 and 2 showed $10000 \mathrm{~L} \cdot \mathrm{mol}^{-1} \cdot \mathrm{cm}^{-1}$ at $364 \mathrm{~nm}$ and $15600 \mathrm{~L} \cdot \mathrm{mol}^{-1} \cdot \mathrm{cm}^{-1}$ at $350 \mathrm{~nm}$, respectively. 


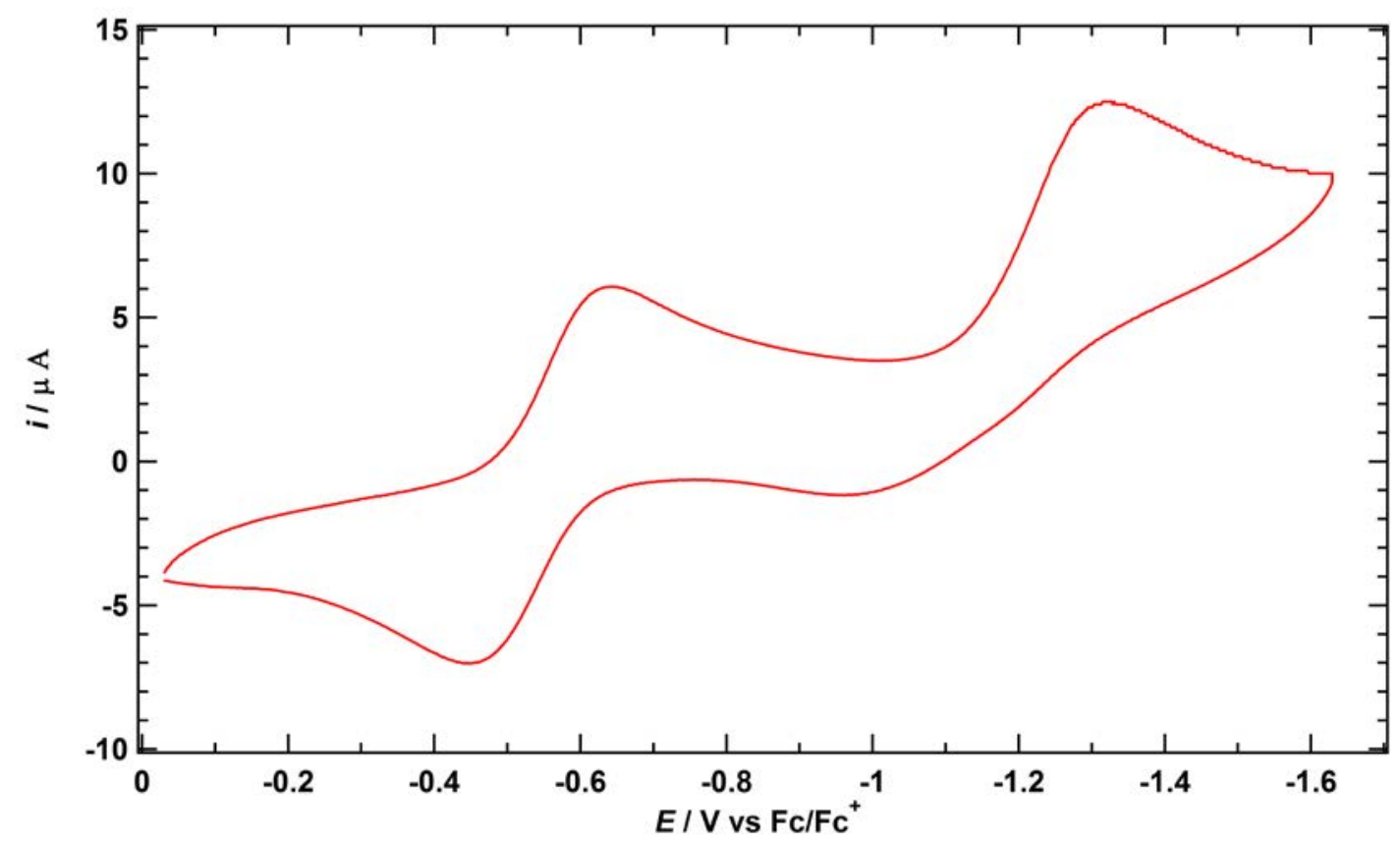

Fig. S4. Cyclic voltammogram of $2\left(2 \mathrm{mmol} \mathrm{dm}^{-3}\right)$ in DMSO $\left(0.1 \mathrm{M} \mathrm{Bu}_{4} \mathrm{NPF}_{6}\right)$. The scan rate was $100 \mathrm{mV} \mathrm{s}^{-1}$. 


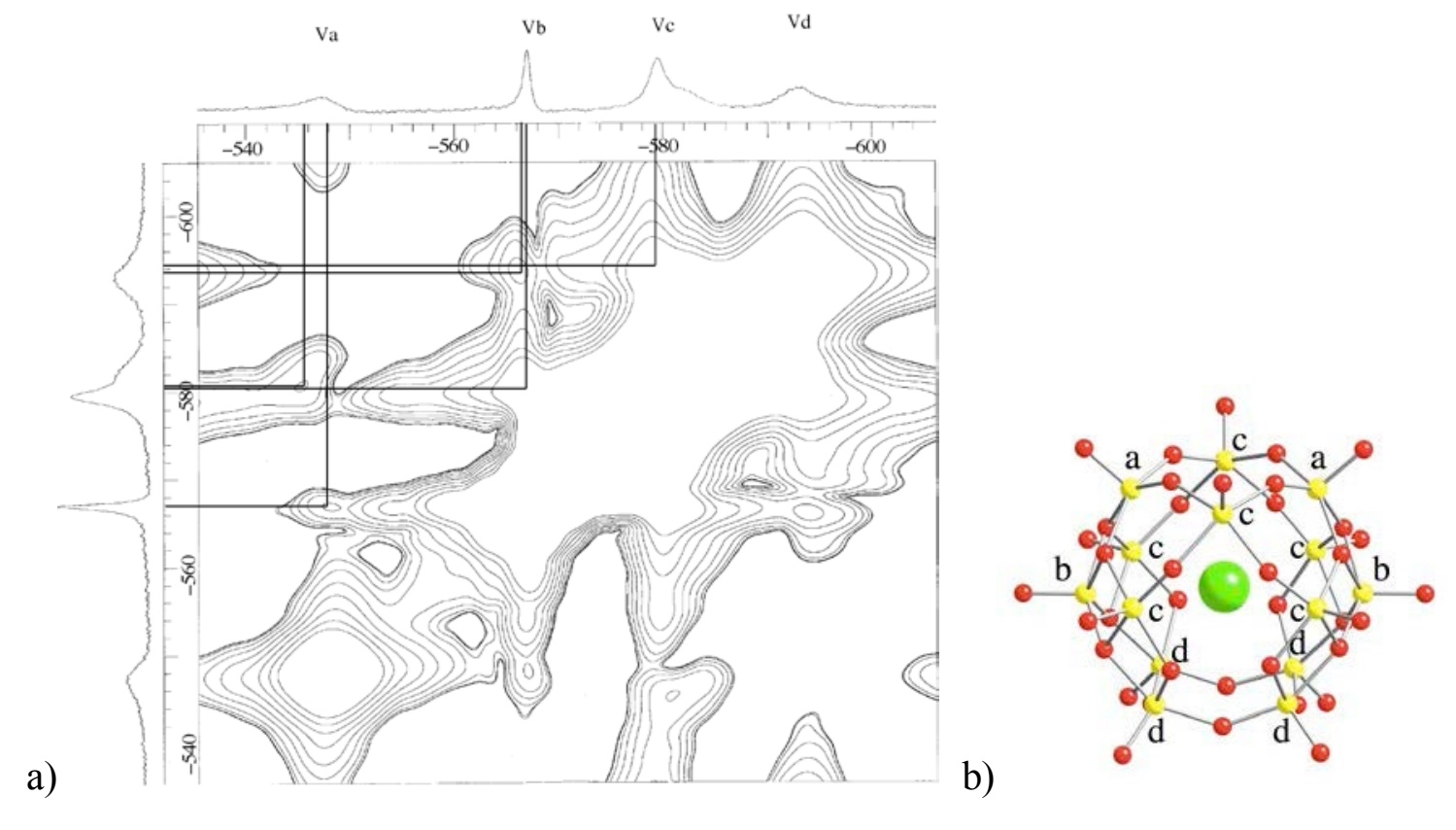

Fig. S5. ${ }^{51} \mathrm{~V}_{-}{ }^{51} \mathrm{~V}$ COSY spectrum of 2 in acetonitrile- $d^{3}$ at $70^{\circ} \mathrm{C}$ : a) $2 \mathrm{D}$ spectrum of 2 ; b) one of the assignments to satisfy the correlations observed. Some of the cross peaks were not observed due to the broadness of the signals. 